\title{
MAQUIAVEL NA FORMAÇÃO REPUBLICANA DOS ESTADOS UNIDOS DA AMÉRICA DO NORTE: UMA POLÊMICA NILO HENRIQUE NEVES DOS REIS ${ }^{1}$
}

\begin{abstract}
RESUMO: algumas interpretações revisionistas estadunidenses têm sugerido que o pensamento de Maquiavel está presente na história intelectual de formação dos Estados Unidos. Essa mensuração é um elemento significativo para refletirmos sobre a influência maquiaveliana em solo norte-americano; neste sentido, a vigência de um autor deve ser identificada nos traços que apontam a aceitação e/ou recusa de suas teses aplicadas para a prática e teorização. É com esse juízo que se pode afirmar se, de fato, ocorreu alguma influência de um autor em dada perspectiva política diversa. Neste artigo, demonstraremos que, independentemente das posições, as obras de Maquiavel receberam atenção de personalidades instruídas ao longo da formação do pensamento político nos Estados Unidos. Essas mesmas personagens não deixariam de se imiscuir com as ideias por conta do aspecto religioso, mas, por razões óbvias, tais leitores não estavam dispostos a sofrer sanções sociais em nome de uma controversa aproximação.
\end{abstract}

PALAVRAS-CHAVE: Maquiavel; Estados Unidos; Influência.

\begin{abstract}
Some US revisionist interpretations have suggested that Machiavelli's thinking is embedded in the intellectual history of the United States foundation. This measurement is a significant element to reflect on the Machiavellian influence on North-American soil; in this regard, the validity of an author must be identified in the traits that point to the acceptance and/or refusal of his theses applied to the practice and theorization. It is with this judgment that one can affirm whether, in fact, some influence of an author occurred in a given political perspective. In this article, we will demonstrate that, regardless of positions, Machiavelli's works received attention from highly instructed personalities throughout the formation of American political thought. These same figures would not fail to meddle with the ideas because of the religious aspect, but due to obvious reasons, such readers were not willing to suffer social sanctions on behalf of a controversial approach.
\end{abstract}

KEYWORDS: Machiavelli; United States; Influence; Political formation.

\footnotetext{
${ }^{1}$ Professor Titular (Pleno) de Filosofia da Universidade Estadual de Feira de Santana (UEFS). Doutor em Filosofia pela Pontifícia Universidade Católica de São Paulo (PUC-SP) E-mail: niloreis@uefs.br.
} 
Foi necessário ter sido, em grande parte, desaparecida a geração que tinha vivido sob os papas sem escrúpulos, sendo o último destes o Farnese, para que se começassem a estudar os vetos contra os livros, que, por muitos, se não por todos, acreditava-se serem perigosos. Mas a princípio se precedeu com notáveis irresoluções. Busini, já citado, em uma carta de Roma que se assegura pertencer a 1549, assim escrevia: "Aqui são proibidas de se vender todas as obras do nosso Maquiavel, e querem fazer uma excomunhão a quem as tenha em casa; até aqui nenhum livreiro pôde as vender, se não sob graves penas. Deus ajude Boccaccio, Dante, e Morgante e Burchiello". As perseguições aos autores e aos livros invisíveis, ocorreram em todos os tempos; mas esta forma de proibição, que alcança depois o subsídio dos Índices, era um achado novíssimo, cuja atuação devia encontrar não pequenas dificuldades; e, certamente, também aquela ordem severa de Roma não foi, sob as primeiras ao menos, e em geral, executada. Muzio, solicitado pelo Comissariado geral de Cardeais Inquisidores que indicavam os livros que lhes pareciam dignos de serem proibidos, respondia que, não tanto contra os hereges quanto contra os infiéis, pedia-se para pegar em armas; dentre estes está Maquiavel, que sem respeito algum ensinava a não observar a fé (BONGI, 1897, p. 127).

Salvatore Bongi (1897) mostra as premonitórias da Igreja contra a obra de Maquiavel em Roma, ao que Reginald Pole (2013) acresceu a compreensão de que "Satanás"2 usava as letras do florentino para continuar sua luta com a humanidade. Nessa convicção seguia o cardeal Gian Pietro Carafa, que, posteriormente, tornando-se o Papa Paulo IV, não apenas se contentou em cobrir "as vergonhas" das pinturas na Capela Sistina, como criou o índice de livros proibidos, Index Librorum Prohibitorum (Index), no qual colocou Maquiavel. Os defensores da religião viveram à custa do controle da moral, alheios às verdades que não se encaixavam na sua "superioridade espiritual", defendendo sua propriedade e banindo qualquer ameaça. A Maquiavel estava reservada uma censura prévia, visto que sua imoralidade era, com certeza, fonte de subversão; daí porque o maquiavelismo fosse a chave colocada de maneira obscura aos fiéis, aos que desejavam conhecer a verdadeira palavra para se salvar e que não tinham acesso à fechadura, à porta que escondia o conteúdo de Maquiavel, sem interpretações distorcidas. Colocando imagens que não reproduziam os fatos, criou-se a figura de um autor que era reconhecido bem antes de suas ideias. Porém, nada disso impedia, sequer, as obras de serem transportadas entre cidades por mares distantes. O "demoníaco" florentino era levado a todas as pessoas instruídas que desejassem conhecê-lo, mesmo a contragosto à posição oficial da Igreja.

Na França, os principais escritos de Maquiavel circulavam sem quaisquer óbices das autoridades, mesmo depois de serem inclusos no Index,

em 1559, que proibia os católicos de ler, então, as obras do Florentino, sanção que será então reconfirmada em 1564 pela Comissão de revisão nomeada pelo

\footnotetext{
${ }^{2}$ Para Pole (2013), Satanás usaria os dedos de Maquiavel para influenciar o rei Henrique VIII a agir contra a Igreja Católica. Ver Apología ad Carolum Quintum Caesarem; In: El Cardenal Pole, de la política como virtud en tempos de El príncipe. Madrid: Unión Editorial, 2013.
} 
Concílio de Trento. Na Itália essa condenação levou à prisão de todas as reimpressões, enquanto na França, ao contrário do que acontecia na península, mas também na Espanha e na Inglaterra, as obras de Maquiavel continuaram a circular abertamente para serem traduzidas, impressas e oferecidas a personagens eminentes da Corte durante a segunda metade do Cinquecento (BENSIMON, 2013, p. 177).

Não se conclua que esta liberdade continua sem limites no tempo, apesar da notoriedade e prestígio que as obras de Maquiavel desfrutavam na França, no decurso dos fatos, e, talvez, pelas decorrentes insinuações nocivas da influência de $O$ Príncipe, a rainha da França, Catarina, filha de Lorenzo de' Medici, a quem Maquiavel dedicou a mencionada obra, com a fatídica "Noite de São Bartolomeu", condenou o escrito.

Embora a situação da Espanha já tenha sido descrita, de acordo com Helena Puigdomènech (1988), só um pouco mais de uma vintena depois da proibição do Index que se iniciaram as perseguições às obras (BARTUREN, 2013). Antes das ações dos inquisidores, porém, tais escritos tiveram a oportunidade de serem lidos por pessoas instruídas. Esta leitura, como se sabe, parece ter ocorrido em todos os locais em que as obras chegaram. Afinal de contas, era natural que um livro extraordinário, cujas ideias mostravam os bastidores do poder de forma inédita e, igualmente, discutia diversos aspectos do fenômeno político, servisse às mentes inteligentes e as influenciasse, ainda que, de resto, estas nada fizessem para modificar a estrutura do domínio em que viviam. A obra do florentino não podia ser ignorada, pois ela acrescentava algo que, por estilo e conteúdo, não estava presente nos livros anteriores, motivo pelo qual, mesmo estando entre as melhores produções da época, ao julgamento dos que se deleitavam com as ideias dos humanistas, era considerada perniciosa e não devia ser lida ou levada para casa pelos cristãos.

Talvez o ponto mais surpreendente acerca da recepção das obras de Maquiavel em cada canto do globo não seja a real demarcação das datas, mas que tipo de influência causou em seus leitores, que, na maioria das vezes, nem ao menos puderam expressar abertamente este fato. Entrementes, não existem modelos pelos quais se possa mensurar tais influências, pois o julgamento da obra depende umbilicalmente dos olhos que contemplam as letras. Conforme Serena Spazzarini (2013, p. 195):

A história das primeiras traduções de $O$ Príncipe para o alemão na Alemanha beira uma margem de reserva prudencial, senão mesmo de sigilo intencional, por parte dos tradutores ou editores, que de vez em quando se preocupavam em divulgar aquele texto 'proibido', sendo fácil entender por que a primeira tradução alemã permaneceu manuscrita e limitada a um pequeno círculo de leitores, sem nunca cruzar as fronteiras do pequeno Principado Salesiano de Oels. 
A circulação dos textos maquiavelianos na Alemanha parece seguir um roteiro quase comum a outros lugares, isto é, trata-se de uma obra apreciável, cujos exemplares encaminhavam-se de bolso a bolso, sendo seu autor glorioso, porém, pouco citado. Este modus operandi parece assegurar um lugar ao florentino na república dos escritores de política, mas até certo ponto, pois poucos são aqueles que discutem suas perspectivas de modo confesso. Segundo Francesca Terrenato (2013, p. 208), em 1615 apareceu a primeira tradução de $O$ Príncipe na Holanda; ademais,

\begin{abstract}
esta não é a primeira aparição de Maquiavel na cena holandesa. No polêmico papel de conselheiro de soberanos tirânicos, já era conhecido nos meios intelectuais, que o liam em italiano ou latim, desde o final do século XVI, como evidenciado pela acusação de imoralidade que o humanista Justus Lipsius lhe fez em sua Política, de 1589. Uma atitude generalizada entre acadêmicos e escritores da época era criticar o oportunismo e o ateísmo de Maquiavel, enquanto se inspiravam em suas obras.
\end{abstract}

É à luz destas perspectivas que se deve buscar e compreender a extensão da influência das obras de Maquiavel em seus leitores, já que, mesmo censurado e vilipendiado por diversas inclinações interpretativas, ele é incorporado na dimensão existencial de seus leitores, ainda que seja para ser recusado como um teórico da política e/ou que tais críticas sejam contaminadas de moralismo suspeito. E como dirá Rousseau (1978) ao seu tempo, a ênfase da influência de Maquiavel é enorme, pois a defesa das instituições republicanas estava oculta em seus ensinamentos, afinal de contas, o mundo ocidental era dominado por uma perspectiva predominantemente cristã e avessa a qualquer tipo de oposição.

Diante das recepções apresentadas, por analogia, é possível afirmar que a obra de Maquiavel transcendeu as fronteiras de Florença e circulou por várias partes. Na Inglaterra não foi diferente, conforme atestam Alessandra Petrina (2009; 2013), Napoleone Orsini (1937) e o preservado documento The Charlecote Manuscript of Machiavelli's Prince (WHITFIELD, 1967). Christopher Hill (2003) garante que a leitura da Bíblia em sua forma vernacular teve uma função significativa para os ingleses, permitindo moldar diversas interpretações que serviram como fonte de contestação à autoridade e tornando-se, ao mesmo tempo, uma matriz norteadora para os indivíduos. Foi nesse ambiente que a religião passou a ser uma questão fundamental para os indivíduos. E se os conflitos políticos se acirraram na Inglaterra com o reinado de Carlos I, foi graças à leitura da Bíblia que outros embarcaram em navios para fundar uma terra sem apostasia na outra margem do Atlântico, colocando a fé como um pilar da colonização. Talvez, por isto, os colonos tenham evitado ler Maquiavel, para fugir da condenação ao inferno; mas uma coisa era certa na Inglaterra de 1640: lia-se muito o florentino, 
conforme atestam Felix Raab (2013) e Pocock (2003). E se os colonos anglo-americanos não se interessavam pelas obras maquiavelianas, principalmente no que trata do realismo político, resta estranha a passagem de Jefferson transcrita, no literal, por Paul A. Rahe (2010, p. 209, grifos do autor):

Na verdade, diante dos meus olhos, não tenho senão Locke, Sidney, Milton, J. J. Rousseau e Th. Payne; esta é minha biblioteca inteira; eu queimei o resto, exceto Maquiavel, a quem todos os diplomatas possuem, embora não se atrevam a confessar e a quem os homens livres deveriam colocar ao lado da Declaração de Direitos.

Decididamente, este trecho causa um inconveniente nas convicções mais íntimas, já que Thomas Jefferson é uma figura proeminente na temática em lide. Entretanto, a questão se torna problemática quando se avalia a reação dele a esconder/desvelar o Maquiavel inconfessável; Jefferson seria uma chave ou um enigma? No que diz respeito às duas perspectivas, se, por um lado, as posições revisionistas que desejam reescrever a história dos Estados Unidos da América sob influência maquiaveliana podem ser acusadas de indevidas e precipitadas, por outro, não restam dúvidas de que cabem reservas ao simples negacionismo dos que estão vinculados a uma tradição comum, como no caso dos colonos anglo-americanos. Nesse aspecto, é bom lembrar das palavras de Lefort (2010, p. 11), que afirma: "antes de ler Maquiavel, você já tem uma certa noção do maquiavelismo. Embora tudo sobre o homem e sua obra seja ignorado, o termo é usado sem hesitação".

\title{
A presença dos textos maquiavelianos no ambiente político inglês: dissensões e aparências
}

\begin{abstract}
Afirma-se que certos padrões de resistência na consciência temporal dos europeus da Idade Média e aqueles do início da modernidade levaram à apresentação da república, e à participação do cidadão, como constituindo um problema no autoentendimento histórico, com o qual Maquiavel e os seus contemporâneos podem ser vistos tanto explícita como implicitamente. Tornou-se crucial no seu tempo e assim permaneceu, em grande parte como resultado do que eles fizeram com isso, durante dois ou três séculos depois. Sua luta com este problema é apresentada como historicamente real, embora seja selecionado como aspecto da complexa realidade histórica do seu pensamento; e o seu "momento" é definido como aquele em que enfrentaram o problema tido como crucial (POCOCK, 2003, p. VII-VIII).
\end{abstract}

John Greville Agard Pocock traz, em The Machiavellian moment, o debate republicano como uma decorrência da crítica aos fundamentos de verdades transcendentes que organizavam a vida social e, em simultâneo, do dilema de uma construção humana espacial que luta para resistir às intempéries da existência. Se o ambiente inspirava atitudes republicanas, é certo que, para Pocock (2003), traços deste pensamento podem ser sentidos no final do século XIV em Florença, fazendo-se presentes também nos desdobramentos dos centenários seguintes, até atravessarem o oceano Atlântico. Ele o faz ao mostrar como o ideal humanista cívico estava em 
desenvolvimento ao longo de toda uma teia histórica. Todavia, para o autor, foi graças às ingerências dos humanistas cívicos - que trouxeram o discurso do republicanismo, com a contribuição de Maquiavel, - que a natureza do problema político da sociedade voltou ao debate e que este foi tomado como pressuposto na construção dos fios. Em razão das influências que suas obras produziram, o referido pensamento ganhou uma acolhida inédita na Inglaterra e, depois, na América. Não obstante, Pocock (2003) valoriza na sua análise as circunstâncias do contexto e, em especial, como as obras foram compartilhadas e afetaram os seus leitores. Daí, o próprio florentino era um teórico envolvido nas tramas dos fios enquanto leitor e produtor de textos que, lidos, ganham contornos inusitados. Ademais, como bom leitor da tradição e com motivações no uso de palavras, o florentino se encaixa no perfil daqueles autores que têm uma dívida com a herança dos que defendem a perspectiva republicana como melhor regime de governo para o cidadão. Mas como era vigiado por aqueles que dominam o poder, recorreu a estratégias para defender um governo livre e sob o império das leis, escamoteando ou velando sua posição pessoal com palavras mais ou menos transparentes, a fim de encobrir o que não poderia ser dito abertamente. E foi, quiçá, pensando na ingenuidade de Piero Soderine para lidar com seus desafetos na instável república florentina, que usou os capítulos 7 e 8 dos Discorsi $(2007)^{3}$ para mostrar que o emprego da "denúncia" e da "calúnia" poderia ter sido utilizado como um expediente para eliminar seus adversários, que, sempre com imputações mentirosas, desestabilizavam o frágil governo, sem sofrer as consequências com os enganos usados de modo propositado para prejudicar sua administração. Maquiavel tinha noção de que as instituições não tinham como se tornar sólidas sem a presença dos cidadãos que nelas atuam e as respeitam, temendo inclusive o peso das leis quando suas ações não fossem exemplares para fortalecer as próprias instituições. A virtude cívica era fundamental para a preservação das instituições, e estas estão a serviço dos homens livres. Este pensamento de Maquiavel colocou em destaque, aos moldes aristotélicos, a natureza política do perfil de um cidadão.

Seguindo as diretrizes da Escola de Cambridge, Pocock (2003) discorre sobre como o pensamento maquiaveliano, em estreita relação com os teóricos que se inspiraram na tradição republicana, trouxe a perspectiva de cidadania de Aristóteles ao debate e incentivou os ingleses a participarem das decisões políticas no governo. A reflexão de Maquiavel nasce da interlocução com outras obras de escritores políticos florentinos e com a percepção do que foi produzido no passado. Este duplo alargamento ganha uma direção reflexiva para o secretário a serviço de Piero Soderine, que percebe na participação política, no governo republicano e na

\footnotetext{
${ }^{3}$ Discursos sobre a primeira década de Tito Lívio.
} 
soma da virtù do cidadão, o caminho para se agir na construção de uma cidade livre, o que lhe era natural.

A convergência de aspectos funcionaria como uma crítica à vida contemplativa e, inversamente, faz a apologia de uma vida ativa, já que o indivíduo, em contato com as palavras, não só toma consciência de si, como é levado a tomar consciência das estruturas sociais do universo em que habita.

O escrito de Pocock (2003) ressalta este ambiente maquiaveliano existente na Inglaterra e que, para ele, foi transportado para Escócia e América. As obras do florentino foram absorvidas pelos leitores ingleses, que a utilizaram conforme sua própria interpretação, mas dentro de um contexto histórico propício ao uso do vocabulário maquiaveliano para analisar o fenômeno político.

De acordo com Pocock (2003), graças à linguagem e seu uso das palavras, das quais não se tem controle nem previsão de resultados, o interlocutor consegue proporcionar um sentido à sua existência e às suas escolhas. Mas é o contexto que lhe abre acesso às palavras e ao saber do presente e do pretérito. Daí a importância das produções das obras (e não só as canônicas) para se familiarizar com o vocabulário, os conceitos e os temas que estavam circulando. É o contexto que expõe as perspectivas, molda definiçõos e discursos e permite a formação de uma visão de mundo, já que os discursos que buscam influenciar querem atingir um determinado auditório, visto que sua inclinação faz parte de um propósito político. Não obstante, o contexto é absorvido por uma mediação crítica. O vocabulário, as ideias, valores e ações são dotadas de intencionalidade, motivo que as leva a serem divulgadas em obras, manuscritos, jornais e panfletos, que são produções dos atores sociais que interagem pela linguagem com o meio e, assim, estão relacionadas com a construção da realidade político-social. Para Pocock (2003), os ingleses se apropriaram dos conceitos e valores presentes nos escritos de Maquiavel, sendo James Harrington (2010) o teórico que tomou consciência desta influência ao unir o pensamento humanista e cívico às contendas políticas que ocorriam na Inglaterra em sua obra The Commonwealth of Oceana, que, depois de publicada no ambiente inglês, foi levada para as colônias anglo-americanas.

Uma vez tomada a decisão de usar o vocabulário maquiaveliano na interpretação da política de sua época, era imprescindível escolher judiciosamente acerca do emprego dos termos, bem como do acompanhamento pelo vocábulo "Maquiavel", que fazia parte do aporte teórico para o conhecimento do problema político e do encaminhamento de viés republicano. No entanto, era inegável que, para a tradição moralista, a simples menção da palavra Maquiavel 
era sempre entendida como perniciosa e se constituía como um óbice para aceitação argumentativa por parte de outrem, pelo menos aos espíritos mais sensíveis, aqueles que eram dominados pelo excessivo respeito à própria pele ou ao escárnio social. De qualquer modo ou aspecto que se analise, o tema da presença do cidadão armado e participativo na condução dos negócios estatais não se deu por geração espontânea, nem foi fruto da imaginação genial de um escritor que, um dia, decidiu escrever como profeta, renunciando às ideias e ao vocabulário que estavam à mão; são decorrentes do encontro das ideias, das interlocuções (pretéritas e do presente) e do contexto histórico, motivo que levou Pocock (2003) a buscar não só os textos canônicos, mas toda uma produção não de acordo com os cânones, bem como cartas, cartazes e manuscritos que permitiram visualizar o conjunto complexo das situações e o modo como as palavras foram empregadas para expressar as intenções dos autores e as interpretações dos leitores, o que resta óbvio, ao final, para Pocock (2003), é que este momento maquiaveliano se constituiu na Inglaterra, e com o decorrer do tempo, com suas ideias e vocabulário, foi transportado para a América do Norte.

É preciso observar que, de acordo com a tese de Pocock (2003), havia na Inglaterra um ambiente propício à discussão política e que os textos de Maquiavel foram utilizados por vários escritores ingleses, não restando dúvida da circulação das ideias do florentino na Inglaterra. Essa intimidade com os escritos maquiavelianos na ilha inglesa havia ocorrido no passado com Thomas Cromwell, Richard Morison e Reginald Pole. É indispensável não desconsiderar que em a Apologia ad Carolum Quintum, Pole exprimiu um juízo de valor danoso ao pensamento de Maquiavel, que, ligando a Inglaterra, Roma e Espanha, tornou-se a compreensão do cristianismo a respeito do florentino: a opinião de que havia o dedo de Lúcifer em suas palavras. Logo depois, “Ambrogio Caterino, quem denuncia o ateísmo dos Discorsi, colocou-o entre os livros que os cristãos devem abominar. É um bispo português, a quem o segundo capítulo do Livro II dos Discorsi parece um pedido de desculpas ultrajante para o paganismo" (LEFORT, 2010, p. 19). Essa imagem maléfica se espalhou pelos mares navegáveis, favorecendo o justo entendimento de que, "antes de ler Maquiavel, já se tem uma certa noção do maquiavelismo. Apesar de se ignorar tudo sobre o homem e sua obra" (LEFORT, 2010, p. 11). Portanto, se as ideias do florentino eram conduzidas de um lugar para outro, junto também seguia a nódoa moral, o que levava seus leitores a serem inconfessos, mesmo quando aceitavam ou refutavam suas teses, o que é, de fato, a prova inconteste de que eram seus leitores.

Não se deve desconsiderar que os colonos estavam envolvidos com a linguagem, instituições e tradições inglesas, encontrando-se vinculados de tal monta que suas ações e 
palavras guardam um elo com a metrópole, ainda que estivessem fazendo uma mediação ininterrupta com os fatos que os circunscreviam. Pocock (2003) trouxe à baila a ideia de que os humanistas cívicos, no século $\mathrm{XV}$, tiveram acesso às ideias e vocabulário da teoria republicana e, articulando as suas próprias eventualidades e contingências, moldaram uma forma de entender o fenômeno político. Na Inglaterra, esta tradição aristotélica, acrescida da visão maquiavélica, através dos que se entusiasmaram com uma plêiade de autores que leram os florentinos, ganhou contornos que foram decisivos para a compreensão da fala e da ação política nas colônias anglo-americanas, ainda que a história destas localidades tivesse um sentido diferente daquele que ocorreu primeiro em Florença e depois na Inglaterra. A tradição republicana clássica foi tomada sob a influência inconfessa de Maquiavel. De mais a mais, o que realmente importa nesta quadra do tempo é reconhecer que a tese de Pocock (2003) é digna de crédito e deve ser mais do que contendas de pesquisadores afeiçoados às suas perspectivas.

\section{Por uma defesa: a impossibilidade de precisarmos a influência maquiaveliana na formação do republicanismo estadunidense}

Como Maquiavel, Hamilton sabia que, durante a maior parte da história da humanidade, o preço moral da liberdade para alguns tem sido seu domínio sobre outros. Em seu primeiro panfleto político, Hamilton citou David Hume, que estava parafraseando Maquiavel, a fim de argumentar que governos livres que também são impérios poderosos, como a Inglaterra em 1775 e Roma antes dela, tornam os tiranos mais cruéis sobre suas províncias conquistadas, as quais eles exploram para seu próprio benefício (WALLING, 2010, p. 276-277).

Karl-Friedrich Walling indaga: Alexander Hamilton foi um político Maquiavélico? Aliás, este é o pretexto que se propõe a refletir na sua cooperação para o livro Machiavelli's liberal republican legacy, obra editada por Paul A. Rahe (2010), que deu mais impulso ao debate de como o pensamento político maquiaveliano contribuiu para a promoção do republicanismo na história dos Estados Unidos; a polêmica, contudo, está longe de um consenso. O próprio título já é provocador em si, o "Legado republicano liberal de Maquiavel"; conquanto, entre revisionistas e contestadores que moldam seus edifícios majestosos alicerçados em suas pesquisas, acredita-se que as obras do autor em pauta estavam ali à disposição de pessoas instruídas e, simultaneamente, constrangidas de publicizar suas ideias ligadas ao florentino.

Maquiavel não foi apenas um teórico da política, ele foi Maquiavel! É claro que nos auditórios universitários, onde a reflexão política acerca do pensamento do florentino triunfou, não se importa acentuar quem são os seus bons leitores e, portanto, especialistas. Porém, se não fosse a tradição "perniciosa" que se conserva quanto ao "mito maquiavélico", até ali poucos se sentirão à vontade de serem conhecidos como tais. Porque Maquiavel, como foi exposto, não é 
somente Maquiavel! Diferentemente dos socráticos, agostinianos e foucaultianos, os leitores do florentino não querem ser identificados como "maquiavélicos", o que revela o quanto ainda pesa como ofensivo o referido vocábulo, mesmo na academia. E não se trata do caráter conservador da vida universitária, mas da civilização ocidental, fortemente influenciada pela visão cristã, que tem uma imagem simbólica negativa sobre o substantivo adjetivado que expressa, em si, todos os vícios humanos com uma perífrase.

A história da interpretação pública de $O$ Príncipe, não raras vezes, foi perniciosa, e, independentemente das boas leituras ou não quanto à obra, ela tem produzido influências perenes, ainda que poucos queiram admitir que se inspiraram no florentino para realizar sua produção. De mais a mais, as obras de Maquiavel se tornaram referenciais para a interpretação do fenômeno político, dando ao leitor uma compreensão a respeito de "confrontos mortais entre facções, golpes de Estado, assassinatos, agressão e derrota na guerra" (BARZUN, 2002, p. 289), mesmo quando sua menção acontece apenas para fazer a glosa de determinado fato político. Sob este ponto de vista, não se crê na afirmação de Luigi Marco Bassani (2009, p. 379) de que, nos EUA, as “ideias (de Maquiavel) não eram vistas como exclusivamente imorais, tais como foram no passado", muito menos que os colonos anglo-americanos, do final do século XVIII, tivessem vencido este preconceito à época. Uma coisa era simétrica, ao lado do nocivo e prejudicial: o florentino tinha se tornado um ponto de inflexão para o pensamento republicano clássico ou das coisas que acontecem na política. Desse modo, não tinha como se imiscuir de um teórico que teve a sensível consciência de entender como o homem realmente era, e não, como ele deveria ser. Maquiavel precisava ser lido pelas pessoas instruídas da colônia, antes de mais nada, porque ele não caía nos caprichos da retórica idealizada, mas sim em torno de sua análise das coisas do Estado, fornecendo as chaves do enigma político. Além disso, O Príncipe e os Discorsi jamais deixaram de ser lidos, ainda que o fossem de maneira inconfessa, pois sempre houve leitores que foram influenciados por seus pensamentos, mesmo quando se recusaram a seguir o conteúdo das obras. Assim, por mais surpreendente que pareça tal afirmação, quem não aceita o exame do florentino, não deixa de ser um leitor. No que diz respeito à influência, até a recusa, se não compreendida corretamente, pode ser um indício claro de que o leitor trava um combate, mesmo que não mencione o invisível alvo de sua contenda. Francesco Guicciardini, Donato Giannotti, James Harrington, Marchamont Nedham foram leitores confessos de Maquiavel; outros, inconfessos, recorreram a artifícios para evitar 
desconfortos ${ }^{4}$ vinculando-se ao teórico que revelou a face humana ao descrever que os homens "são ingratos, volúveis, simuladores e dissimuladores, arredios aos perigos, ávidos do lucro; e enquanto lhes fazes bem são todos teus, oferecem-te o sangue, os bens, a vida e os filhos (MAQUIAVEL, 2017, p. 193-195). Não se deve desconsiderar que, no início do século XVII, circulavam ideias de que os ingleses acreditavam ser o "povo eleito", a nação escolhida por Deus, mas quando chegou a década de 1630, “o tema do abandono de Deus em relação à Inglaterra tornou-se senso comum" (HILL, 2003, p. 403), o que levou muitos para além-mar, procurando fundar uma Nova Inglaterra, fiel às palavras do Senhor. Foi nesse cenário de irmandade em Cristo, de atenção às purezas da fé e de zelo religioso que Maquiavel viveu como o inimigo invisível das palavras bíblicas. De qualquer forma, a leitura de um clássico é indispensável, e a influência que gera uma interlocução reflete-se no modo estranho, e às vezes oposto, às correntes de interpretações tradicionais, desvelando o encanto que provoca no leitor do escrito, ainda que os sinais patentes desta autoridade não se deixem perceber claramente nas expressões dos influenciados.

De acordo com Lutz (1984, p. 192), o Deuteronômio foi o "livro mais citado pelos americanos durante a era da fundação"; o que não deixa de ser significativo é que colonos afastados da metrópole, lutando todos os dias pela sobrevivência, tenham buscado justamente esta parte da Bíblia para acalentar seus corações. Foi neste quinto livro de Moisés que ele exortou a fiel observância da lei de Deus para que a aliança trouxesse a prosperidade ao povo de Israel, já que a bênção divina era fundamental para o empreendimento na terra prometida. Além da observância à lei e do amor a Deus, era cogente seguir os seus ensinamentos, prescritos pela religião, e um padrão moral alto. E como os judeus evitaram uma aproximação com os cananeus, os colonos concentraram sua confiança nas palavras dos sacerdotes que, certamente, já evitavam Maquiavel há tempos. Como na Bíblia, os judeus, através da aliança, comprometiam-se a não se aproximar dos cananeus para não se contaminar com suas crenças e, assim, suportar a fadiga e o sofrimento do deserto com as mais altas virtudes cristãs; na colônia, seus habitantes evitavam louvar ou mesmo divulgar os imoralistas, principalmente o florentino, que não se importava com os vícios da humanidade e a tradição de imaginar homens e instituições perfeitas. De qualquer maneira, as pessoas seguem convenções instituídas pelas relações sociais, ainda que estas sejam, a todo tempo, mediadas por elas, sendo elas, inclusive, basilares na produção de palavras e ações. E quanto aos livros lidos? Tudo indica que eles não

\footnotetext{
${ }^{4}$ Ver: O filósofo e a Censura In: MONTEIRO, João Paulo. Hume e a epistemologia. Vila da Maia: Imprensa Nacional/Casa da Moeda, 1984.
} 
deixaram de desembarcar na colônia para deleite de bibliotecas e pessoas instruídas. Aliás, ao investigar a presença das obras de David Hume na América do Norte, Mark G. Spencer (2005, p. 9) escreve:

quanto mais apreendemos as complexidades do comércio de livros e a propriedade de livros dos americanos no período colonial, mais temos a certeza de que se disponibilizava, buscava-se, comprava-se e se lia livros na América do século dezoito, o que não é tão distante do compasso dos centros culturais europeus como se pensava. E isso se aplica aos trabalhos de David Hume.

Poderia parecer, à primeira vista, que a corrente revisionista, que tem tomado John Pocock como um pioneiro deste modo de pensar, estaria correta em afirmar que o republicanismo clássico navegou da Inglaterra às colônias e, ali, graças às contribuições de Maquiavel e James Harrington, encontraram um solo receptivo para se frutificarem a ponto de, anos mais tarde, influenciarem uma série de escritos que os tomaram como referenciais, o que exigiria uma versão mais atualizada deste posicionamento. Na contramão, destaca-se a observação de Luigi Marco Bassani (2009, p. 381) de que, "até a década de 1770, Maquiavel era considerado irrelevante para a geração que originou a Revolução Americana". O comentador italiano ainda reforça tal compreensão apontando o equívoco desta corrente, já que, antes da aludida década, os estudos mais proeminentes da história intelectual dos estadunidenses sequer mencionam o vocábulo "Maquiavel" entre suas linhas.

A vontade de clareza, por parte dos revisionistas, é bem-vinda, assim como a pesquisa que deve apontar a suposta contribuição ignorada do florentino; entretanto, não se deve desconsiderar que Bernard Bailyn, em As origens ideológicas da Revolução Americana, havia encontrado referências da Antiguidade Clássica, mesmo sem mencionar qualquer relevo aos trabalhos de "Maquiavel" ou um estudo profundo destes. Havia, porém, um vocabulário à disposição de pessoas instruídas. Do mesmo modo, não se deve esperar uma descoberta nostálgica, mas a percepção de que o vocábulo "Maquiavel" é envolto em preocupações, evitado por espíritos discretos e, em silêncio, contemplado por aqueles que são propensos à boa reflexão política. Ademais, o realismo político maquiaveliano se tornou uma exigência na sua própria interpretação do fenômeno político, o que o fez não necessário exteriorizá-la diante de mentes moralistas, distinguindo sua produção do toda aquela que projetava uma realidade civil fundada em descrições imaginadas de sociedade. Graças às suas posições críticas, foi-se obrigando a analisar as consequências da socialização por meio do fenômeno político. Essa concepção não foi bem acolhida pelos escritores da história, que, tendo em vista valores morais, julgaram que certas coisas não devem ser conhecidas pelos homens a fim de que estes sejam 
salvos. No caso singular do florentino, seus escritos foram considerados proibidos e "perniciosos" à humanidade. E tudo indica que:

Aqueles que determinaram prosseguir em seu caminho também foram cautelosos, no mínimo, em reconhecer qualquer dívida aos Florentinos, e não é surpreendente que as ideias de Maquiavel apareçam mascaradas sob diversas formas, mas ainda de maneira inconfundível, sem seu nome ser mencionado (DANFORD, 2010, p. 104).

Donald Lutz escreveu A relativa influência dos escritores europeus sobre o pensamento político americano no final do século dezoito, oferecendo uma profícua contribuição acerca das fontes que inspiraram os estadunidenses na contenda que os levaria à disputa política ao redor da redação das constituições dos Estados e mesmo sobre a forma da declaração de independência. Embora o título do seu artigo revele essa intenção, nem por isso restou claro, ao final, quem terá mais peso, mesmo porque as influências estão embrulhadas em estratégias e até no inconsciente - temos visto que ecos românticos podem ser expostos aos ventos, porém, ideias que são tomadas como nocivas, nomeadamente, por moralistas, tinham repercussões na aceitação por outrem, além de serem um perigo constante à saúde do propositor. De qualquer viés ou aspecto que se tome o poder da influência, ela está presente nos escritores, que ficam à espreita do clima, julgando se o momento é favorável ou não para algo ganhar forma clara ou ser produzido por meio de artifícios, deixando que o tempo o torne conhecido aos leitores menos inclinados à crítica moral.

Para Lutz (1984, p. 196), “os padrões de influência variaram ao longo do tempo”, o que exige novas pesquisas para delimitar a presença dessas influências, sobretudo para compreender que ao lado das escolhas há outras que disputam espaço, com reverberações que soam debaixo das proeminentes. Aliás, Lutz (1984, p. 190) traz ao debate a proposição "de que não havia um escritor europeu, ou uma tradição, ou um pensamento, que dominasse a leitura e a escrita política americana durante o final do ano de 1700", o que não impede, contudo, que certa influência recôndita ganhe espaço inusitado no mapa das próprias influências, inclusive aquelas que não satisfazem corações moralizantes.

Lutz (1984), que sabe o valor da "análise textual" e dos diferentes subsídios de outros investigadores, procurou suplantar a metodologia em foco, preferindo se concentrar na “identificação sistemática dos escritores europeus que precisam ser levados em conta” (LUTZ, 1984, p. 190), o que o induziu a procurar as citações daqueles europeus nas obras escritas, pois:

Uma citação, para os fins do estudo, é definida como qualquer nota de rodapé, citação direta, paráfrase atribuída, ou uso de um nome para exemplificar um conceito ou uma posição. O principal pressuposto é que uma citação indica familiaridade com o autor citado. Além disso, presume-se que a citação é feita por causa dos leitores potenciais que são, também, prováveis a se tornarem 
familiares. Portanto, a contagem de citações indiretamente proporciona um senso da frequência relativa com que os autores europeus foram lidos (LUTZ, 1984, p. 191).

Lutz (1984) estava ciente das críticas de sua opção, especialmente de Bailyn (2003); porém, ao seu sentir, ao recorrer à referência a um texto, fica patente uma familiaridade com aquele que é citado, além da vantagem de não se imiscuir na contenda de que se trata de um louvor ou de uma crítica, e o que resta, de fato, é a ideia de que há um relacionamento da parte de um com outrem.

O vocabulário de um escritor não provém do acaso, uma produção desconexa, pelo contrário, há um vínculo direto com o meio em que vive e onde absorve as palavras e ideias; vínculo este decorrente do caráter contínuo e multifacetado das relações humanas; a batalha decisiva, no entanto, sempre será dada pelo contexto com a mediação do indivíduo. E foi graças a esta última intercessão que a palavra "liberdade" foi ganhando contornos inusitados: embora alguns começassem a entender o seu sentido, a muitos ainda era incerta até onde, e o quanto, poderiam levar os seus efeitos. A colônia anglo-americana estava ligada de várias maneiras à sua metrópole. Suplantando a subserviência política e econômica, havia uma história comum, havia um patrimônio de leituras e ideias, que aos olhos daqueles que tomavam consciência da sujeição irrestrita dos colonos aos interesses da coroa, revelou também um profundo descontentamento. Este sentimento, ao lado da reflexão acerca da liberdade, encontrou solidez nas obras que circulavam nas colônias, além daquelas que foram trazidas entre as posses dos próprios colonos, tornando-se crescente com a inteligência destes últimos e a força e destreza para lidar com eles por parte da coroa. O certo é que, anos depois da guerra civil, o tema da liberdade começava a se espalhar entre os colonos. Em 1640, muitos foram buscar inspiração nas obras de Maquiavel que circulavam na Inglaterra; mas, no século XVIII, o florentino retomou sua adjetivação de escrito pernicioso. Amaldiçoado pelo público, o repúdio moral dava ao nome um toque depreciativo. Não obstante, os habitantes da colônia anglo-americana não surgiram de repente, do nada; eles têm uma história que atravessou consigo o Atlântico e que evidenciou que eles não estavam livres da coroa inglesa, tampouco dos efeitos da leitura das obras maquiavelianas, ainda que fossem mais inconfessos quanto à publicização deste fato. Como bem observou Pocock (2003), foi graças a Maquiavel que se formou um modo particular de pensar a política na Inglaterra, que a liga ao humanismo cívico e à interpretação do fenômeno político, que foi oportunamente designado como o "momento maquiaveliano" que cruzou o Atlântico. Devido a esta afirmação, a colonização e construção dos Estados Unidos da América têm vestígios maquiavelianos. O fato de que tais sinais não podem ser fixados em menções diretas nos escritos dos autores, conforme, então, mostra o estudo de Lutz (1984), não parece 
ser uma evidência inconteste de que, por um passe de mágica, o número de citações a Maquiavel seja baixíssimo, afinal de contas, os ancestrais daqueles colonos conviveram com as consequências políticas, econômicas, sociais e morais de um momento maquiaveliano, o que pede não só a mensuração das citações e a análise textual, como a investigação do uso das teses e a recusa delas por parte dos escritores estadunidenses. E isto envolve uma séria dificuldade, graças à visão maléfica que a palavra Maquiavel tinha na quadra do tempo em lide e aos traços que estão embrulhados em diversas estratégias, para não serem identificadas, o que não quer dizer que não estivessem ali.

\title{
A inexata influência de Maquiavel na formação dos Estados Unidos
}

\begin{abstract}
Adams livremente admitiu, muitas vezes, não ter certeza se Maquiavel falava a verdade ou dissimulava, "se ele estava brincando ou sendo honesto.". Ele também parece ter percebido que havia duas pessoas em Maquiavel: o Maquiavel restaurador das instituições republicanas antigas, e o Maquiavel professor do mal. Anos mais tarde, ele diria do florentino: suas obras contêm uma grande quantidade de sabedoria, embora muitas vezes esteja misturada a muita maldade." Adams extraiu de Maquiavel o que precisava, e rejeitou muita coisa (THOMPSON, 2010, p. 190).
\end{abstract}

De acordo com Thompson (2010), John Adams conheceu bem o pensamento de Maquiavel, a ponto de aceitar a tese "de que a natureza humana sempre foi e será a mesma em qualquer lugar”, e graças a este juízo “a história pode oferecer aos cientistas políticos um tipo de laboratório onde podem observar e comparar a natureza, a origem e o curso de todos os governos" (THOMPSON, 2010, p. 196-197). E este juízo era compartilhado nas Letters on the Study and Use of History, de Bolingbroke, autor que, segundo Thompson (2010), Adams lia com dedicado zelo - e ambos eram admiradores do florentino. A bem da verdade, Algernon Sidney, John Milton, Jonathan Swift e Montesquieu, Marchmont Nedham e James Harrington, por exemplo, eram escritores que tinham uma intimidade com as letras de Maquiavel e, igualmente, eram lidos pelos instruídos moradores da colônia anglo-americana.

As obras maquiavelianas discorrem sobre a potência das instituições e acerca do recurso à fraude e à força para conquistar o assentimento popular, a exemplo d'O Príncipe, ou no que concerne a como os conflitos institucionalizados, nos Discorsi, com a virtù dos cidadãos, podem fazer a grandeza da pátria e gerar a liberdade que se reproduz no respeito às boas instituições. Com a virtú do príncipe ou do cidadão, molda-se o perfil do homem que age nos assuntos públicos.

Pole (2013), sem dúvida, havia percebido, bem antes de todos, que essas concepções eram perigosas à ordenação civil. Na tradição da Igreja cristã, a negação dos assuntos políticos e a busca de beatitude eram valores supremos, coroando o desejo da boa alma, no plano 
intelectivo, com o afastamento das coisas do mundo através de uma vida de contemplação. A análise de Maquiavel, por parte de Pole (COLI, 2009, p. 111) e seus asseclas em Pádua, comprovou-se no decurso do tempo. Os manuscritos que circularam na Inglaterra na sua época fizeram como as sereias: lançaram sons que resultaram no encantamento capaz de conceber uma imagem que transformaria súditos em cidadãos e, depois, estes em súditos, mas com uma nítida distinção: agora eles são súditos com obrigações, mas também homens com direitos invioláveis. Graças ao momento maquiaveliano, uma tomada de consciência permitiu ao súdito inglês retomar a compreensão aristotélica de cidadania.

Pocock (2003) chegou mesmo a escrever em The Machiavellian moment para acentuar a presença da influência das ideias de Maquiavel nas produções e debates ingleses que se estenderam à América. Em certo sentido, essa circulação de escritos de Maquiavel em solo inglês só poderia ter ocorrido se houvesse, ao menos, admiradores de suas concepções. E tal hipótese foi confirmada por Raab (2013), ao mencionar o caso de Richard Morison, que usou os escritos (em referência direta aos Discorsi) do florentino a favor de Henrique VIII em uma de suas controvérsias palacianas, citando, inclusive, Nicholao Macchavello (RAAB, 2013, 34). Decerto que entre aqueles que deixaram a Inglaterra para colonizar as terras do outro lado do Atlântico havia quem admirasse em segredo Maquiavel ou, ao menos, algum escritor que usou o florentino como referência de sua própria produção.

Barzun (2002) desenha claramente, por um lado, a concepção da parte negativa que a palavra Maquiavel suscita, devido, inegavelmente, às imposições da moral religiosa que, condenavam a menção ao florentino; e, por outro lado, que desde cedo suas obras são visitadas, embora poucos façam o reconhecimento público de seu valor. Esse enigma parece sugerir que muitos eruditos estavam fazendo a leitura das obras em segredo, admirando per se os escritos, não querendo ser vistos como pessoas que praticavam o vício de ler Maquiavel.

Honoré de Balzac (2011), sob inspiração maquiaveliana, mostra um problema da história: as escolhas dos fatos que devem ser lembrados a fim de se evitar as turbulências à ordem dominante. As ligações entre o pretérito e o presente são mais complexas do que parecem, principalmente quando envolvem o que deve ser escondido e quando cabem nesse bojo, afinal de contas, "as verdadeiras causas dos acontecimentos" podem não ser dignas de serem vistas. As luzes dos "acontecimentos" devem ser evitadas para que as gerações vindouras não tomem consciência da lógica das transformações, bem como de que modo as ações foram conduzidas. Com isso, evita-se a repulsa moral, componente essencial que a tradição visa 
ignorar ou atribuir exclusivamente aos insurgentes. E a revolução americana seria simbólica de muitas maneiras, como observa Gordon S. Wood (2013, p. 119-120):

O republicanismo era, sob todos os aspectos, uma ideologia radical [...]. O republicanismo dava uma dimensão moral e idealista à separação política da Inglaterra - uma dimensão que prometia uma mudança fundamental nos valores e no próprio caráter da sociedade americana [...] ligando-se às mais antigas e profundas correntes de pensamento europeias, que remontavam à Antiguidade [...]. Essas ideias clássicas foram revividas pelos escritores do Renascimento - Maquiavel, em particular - e transmitidas no pensamento inglês do século XVII por escritores como James Harrington, Algernon Sidney e o poeta John Milton. Foi sob a influência das ideias republicanas que a Inglaterra do século XVII executou o rei Carlos I e tentou um breve experimento republicano.

Com Wood (2013), percebem-se os autores que se tornaram uma referência aos leitores anglo-americanos, encarnando uma espécie de intercessão entre os antigos e sua própria contextualização. A medida da influência pode não ser precisa, mas o que não se pode negar nesse caso é que os anglo-americanos, mesmo com suas contribuições à matriz republicana, são parte de um processo da história inglesa que, em dada quadra do tempo, por uma necessidade política de quem busca a autonomia, tiveram que moldar uma forma para serem conhecidos como outros, distintos de seus pares ancestrais. Os americanos jamais tiveram a intenção de repudiar o que foi de melhor produzido na Europa; e, segundo Wood (2013, p. 125), eles ainda "abraçaram a crença de que a tocha da civilização havia cruzado o Atlântico em direção ao Novo Mundo, onde arderia com chama ainda mais brilhante".

De acordo com Pocock (2003), o vocabulário republicano inglês atravessou o Atlântico e encontrou lugar em solo anglo-americano, sempre mediado pelos indivíduos. Esta parece ser uma hipótese aceitável, sobretudo quando se considera que as ideias são migratórias e ganham tonalidades conforme o contexto. As palavras se aproveitam da força dos ventos para desembarcarem em cidades portuárias longínquas do seu nascimento, máxime quando tais vocábulos não ficam obsoletos com o tempo, apenas se silenciam no interior dos livros, aguardando a ocasião favorável para persuadirem os olhos e os ouvidos com seus fonemas. Essa conexão é o canto que sempre começa na busca da compreensão da justiça e se move em direção à liberdade, encontrando na matriz republicana os meios para contestar a autoridade absoluta.

Sem a presença física do monarca, os vassalos das colônias e os súditos angloamericanos constataram que a distância de quase 5000 milhas do centro do poder deliberativo tinha seus prejuízos, especialmente os relativos à representação deles no Parlamento. Afinal de contas, como sujeitos deste império, suas demandas eram também legítimas (McCULLOUGH, 2006). Essa distância da metrópole, e mais próxima da natureza, no entanto, promovia a leve 
sensação de que se podia ser um ser livre. De fato, contando somente consigo próprio para enfrentar o ambiente natural, oportunizava-se uma série de sentimentos. Essa situação dual tornava-se ainda mais profícua com a leitura de temas que discorriam a respeito de servidão, submissão, tirania, corrupção, razão, autonomia e fruição da liberdade.

A condição aludida se corrobora quando se põe à vista o caso de Josiah Quincy Junior, trazido por Baylin (2003). O colono anglo-americano era declaradamente um amante da liberdade. Em suas leituras, sua sensibilidade era tocada pela persuasão literária de escritores que usaram as obras maquiavelianas como referência, ainda que não faça referência ao florentino. A imagem dele exemplifica o esboço teórico de que a distância de Londres e o hábito de leitura podem incutir ideias e pensamentos em súditos que estão distantes do seu monarca. Com a ausência deste e a má administração de seus representantes, os livros mais valorizados são os que discorrem sobre a liberdade, chegando, às vezes, a fincar raízes profundas em seus leitores.

Apesar do espaço existente entre a metrópole e a colônia, os súditos anglo-americanos tinham a Inglaterra como lugar de expressão cultural, seja nos aspectos positivos, seja nos perniciosos. Além disso, a elite, pelo menos, encaminhava seus filhos para o território inglês com vistas a uma formação mais específica. Uma vez inseridos no ensino formal e nas rodas de debates estudantis, esses jovens tomam conhecimento do pensamento político do pretérito e, sem dúvida, das obras de Maquiavel.

Durante a emigração para as colônias, as famílias levaram consigo seus pertences. Com a fixação nas terras coloniais e, ao mesmo tempo, a recuperação da tranquilidade política na Inglaterra, as elites conduziram seus filhos às faculdades na metrópole, a fim de que eles completassem os estudos superiores. No regresso ao solo anglo-americano, esses jovens levaram consigo seus bens móveis prediletos, e, dentre eles, os livros. E sendo Maquiavel lido em Londres, por certo que seria lido nas 13 colônias.

A década de 1640 não representava apenas a tradução simbólica de $O$ Príncipe na Inglaterra, foi também o aprofundamento da crise política da nação. E aquela fase difícil do processo histórico inglês foi objeto de estudo nas faculdades, tornando-se parte do ensino a compreensão dessa época, bem como as obras que ali circularam. Os escritos dos humanistas foram significativos para a retomada do pensamento aristotélico, principalmente no que toca ao entendimento de cidadão.

É possível, a partir da afirmação de Pocock (2003), pensar que essa ligação, sobretudo porque o discurso do bem comum, da liberdade, da ameaça da tirania, dos freios e controles 
sobre o poder e, em especial, das facções, ocupa uma centralidade na reflexão anglo-americana. Ademais, nos discursos formais e informais da independência dos Estados Unidos da América, houve diversas citações aos clássicos; porém, o termo "Maquiavel" designava algo peçonhento, devendo, portanto, ser evitado.

O Deuteronômio contribuiu de modo mais incisivo, pelo menos em público. Importa sublinhar que as pessoas daquele período concediam uma melhor aceitação ao livro bíblico do que ao danoso e astuto maquiavélico. A recusa em reconhecer essa participação pública levou a incluí-lo entre os clássicos que eram bem mais considerados. Bailyn (2003, p. 43) afirma que esse conhecimento foi "por vezes superficial" em vários autores. Não obstante ao fato mencionado, o autor identifica a influência das obras inglesas (e de toda a história) sobre os estadunidenses na elaboração de certas singularidades no processo de secessão:

Todos os que leram a Boston Gazette, de 26 de abril de 1756, compreenderam a dupla referência - Bibliográfica e histórica - pretendida por um escrito anônimo que terminou um discurso para o povo de Massachusetts - conforme afirmou sem maiores explicações - "com as palavras de Catão para os proprietários da Grã-Bretanha".

Testemunhos da influência única dessa literatura de oposição - evidência dessa grande "hinterlândia de crença" da qual surgiram os argumentos específicos da Revolução Norte-Americana - estão em toda parte nos escritos dos norte-americanos do século XVIII. Às vezes são explícitos, como quando Jonathan Mayhew escreveu que, tendo sido "iniciado, na juventude, nas doutrinas da liberdade civil, como eram ensinadas por homens... como Sidney e Milton, Locke e Hoadly, entre os modernos, gostei deles; pareciam racionais"; ou quando John Adams insistiu, contra o que considerava a opinião comum dos ingleses instruídos, que os princípios fundamentais do bom governo poderiam ser encontrados somente em "Sidney, Harrington, Locke, Milton, Nedham, Neville, Burnet e Hoadly"; ou, novamente, quando listou os grandes pensadores políticos de 1688 mencionando a "Sidney, Locke, Hoadly, Trenchard, Gordon, Platão Redivivus [Neville]"; ou quando Josiah Quincy Junior legou a seu filho, em 1774, "as obras de Algernon Sidney, - as obras de John Locke, - as obras de Lorde Bacon, - Tacitus de Gordon, - e as Cato's Letters. Que o espírito da liberdade pouse sobre ele". Com mais frequência, a evidência é implícita, até o ponto em que os panfletários citavam, plagiavam e modelavam seus textos segundo as Cato's Letters e The Independent Whigs. Sobretudo, sua influência pode ser vista no modo como a peculiar tendência da mentalidade dos escritores dessa tradição refletia nas ideias e atitudes dos norte-americanos (BAYLIN, 2003, p. 59-60).

Consoante Baylin (2003), com a referida manifestação fica evidenciado que os estadunidenses estavam contextualizados com a produção inglesa, a ponto de utilizá-la como referência ou como suporte teórico nas próprias reflexões. Por essa razão, a afirmação de Pocock (2003) insere-se em uma plêiade de autores que notaram como as obras de Maquiavel e Harrington foram lidas de maneira a se formar uma sucessão de escritores neomaquiavelianos 
e neo-harringtonianos. A produção intelectual de uma era não brota prescindindo de sua tradição.

A produção está associada à tradição. No caso anglo-americano, uma coisa merece detida consideração, a saber, o ato unilateral de doação de Josiah Quincy Junior. No documento são listadas obras de Sidney e Bacon como heranças que ele dispõe, depois de sua morte, ao filho. Mas não se trata de meros bens entre outros, pois estão elencados no testamento como uma exigência de que sejam entregues ao filho com o propósito de que a liberdade frutifique em seu espírito. A um proprietário rural, acostumado a meter sementes na terra, não resta outra intenção após o plantio do que, decorrido o tempo certo, seja possível recolher do solo o fruto que ali foi plantado. Essa parece ser a metáfora de Quincy Junior. Como se observa, ele espera que as sementes de liberdade postas nas obras deixadas ao filho possam despertar nele um amor pela liberdade. Quincy conta, ao menos, com esta esperança, pois, no desejo manifesto em testamento, segue implícito o anseio de que a prole leia os autores prediletos do pai.

A crença na liberdade foi o bem deixado por Josiah Quincy aos seus descendentes. Em seu íntimo esperava que esse legado fosse passado às gerações subsequentes. A predileção afetiva vai de encontro à tirania que se alimenta da corrupção moral e que, depois, entrando na máquina estatal, corrompe o sistema até escravizar a liberdade. Esses vocábulos são significativos a Quincy Junior, mas há também um contexto espacial e temporal que promove uma motivação em torno dos temas, dos quais se extrai que os anglo-americanos foram se apropriando no percurso do tempo por conta dos problemas com a administração inglesa.

A análise do gesto de Josiah Quincy também revela o conteúdo das obras, bem como sua posição ideológica, radicalmente oposta aos preceitos estabelecidos pelas autoridades políticas e religiosas. Essa situação histórica permite verificar que havia um conjunto de ideias circulando pelas colônias. Ao contrário do silêncio sobre a influência das obras de Maquiavel, elas estão na base de um discurso favorável à liberdade, formando um espectro da realidade imaginada.

Como se vê, no conteúdo das obras lidas pelos anglo-americanos - visto que Josiah Quincy não era um caso isolado -, percebe-se que "o espírito da liberdade" é o presente do pai ao filho; e mais: os caminhos de Bacon e Sidney passam pela leitura de Maquiavel e por sua maneira de interpretar o fenômeno político. Estes dois autores tomam as perspectivas do florentino como parte integrante de suas próprias posições à medida que dialogam com suas obras. Assim, se a prole aceita a herança, sabe que o pai tinha ciência de que, em algum momento, o filho encontraria a referência ao florentino. Como Bacon e Sidney, o filho de 
Quincy Junior provavelmente lidou com a noção de liberdade enraizada na reflexão política maquiaveliana e, talvez, fez parte do grupo que leu o florentino sem reconhecer o débito com ele pela tomada de consciência de seu entorno. A passagem de Baylin (2003) indica, abertamente, que autores defensores da liberdade eram lidos na colônia. E escritores recorreram a Maquiavel em suas produções.

É inegável que ocorreu, ao menos, uma leitura oblíqua do florentino; o que, do ponto de vista da intertextualidade, sugere que os temas contidos em suas obras encontravam simpatizantes em solo anglo-americano. Mas o silêncio a respeito de Maquiavel era forte. Acredita-se que este fato esteja ligado à influência cristã na maioria dos colonos. Para eles, o mundo só existia pela vontade do Criador, o que faz supor, por sua vez, que tudo que não estivesse ligado a Ele equivalia a trevas. De fato, o colono anglo-americano estava ancorado na fé cristã. Donald S. Lutz (1984) identificou os autores europeus que exerceram influência na América do Norte. Em sua investigação por citações, catalogando apenas os livros que não eram públicos, constatou que a Bíblia foi o mais marcante na era da fundação.

De acordo com Isaacson (2015, p. 14), Thomas Franklin, antepassado de Benjamin Franklin, por exemplo, "manteve a proibida Bíblia inglesa amarrada embaixo de um banco. O móvel podia ser virado a qualquer instante no seu colo para que a Bíblia pudesse ser lida em voz alta, mas imediatamente escondida sempre que um funcionário da corte eclesiástica passasse ali”. Ora, a estratégia é fundamental para superar obstáculos, principalmente porque as fronteiras entre a orientação religiosa e as aspirações políticas podem, às vezes, ser irreconciliáveis.

Nos clássicos, todavia, além de serem associados à boa moral, encontravam-se inúmeros enfoques que podiam ser usados para a reflexão política, sem que fossem vistos como uma crítica à Bíblia. Não se deve esquecer que, graças ao estilo neomaquiaveliano e neoharringtoniano, uma consciência política tinha se formado entre os súditos ingleses, permitindo desfrutar com mais profundidade das produções escritas deixadas pela tradição.

Tomando emprestado abundantemente de pensadores mais originais, eles foram, com frequência, em sua própria época e depois, subestimados como meros divulgadores. Seus conceitos-chave - direitos naturais, a base contratual da sociedade e do governo, a singularidade da constituição "mista" e preservadora da liberdade da Inglaterra - eram lugares-comuns do pensamento liberal da época (BAYLIN, 2003, p. 60).

\section{Conclusão}

Aguarda-se que os revisionistas tragam elementos que comprovem os traços da presença de Maquiavel entre os estadunidenses; todavia, eles não devem impor uma nova história 
intelectual da América sob a influência maquiaveliana porque o seu peso de "perniciosa" arrefeceu-se, tampouco deve-se desconsiderar que gerações de indivíduos floresceram lendo as obras do florentino, mormente quando estes são descendentes da tradição inglesa que criticaram ou justificaram a soberania do monarca lendo os Discorsi e $O$ Príncipe.

Do mesmo modo, não se deve desconsiderar que os indivíduos vivem em sociedades organizadas em instituições que impõem convenções. Para muitos, a colônia anglo-americana simboliza a terra prometida ao povo escolhido, o que possibilitou moldar uma dinâmica de relações sociais sob o domínio do aspecto religioso. Este impôs uma peculiar elevação moral diante do sofrimento externo posto pela natureza, tal qual aquele enfrentado pelos judeus quando vagaram no deserto à espera da terra prometida, em fiel observância às palavras da Bíblia. Mas, do mesmo jeito que o povo hebraico fraquejava na fé, aos instruídos na república das letras, ler Maquiavel era uma maneira visionária de entender como funciona a natureza perante a inclinação dos desejos. Se havia a promessa de que o povo escolhido ganharia a terra prometida, era preciso entender e organizar a vida coletiva deste mesmo povo. E, neste caso, os líderes não seriam santos, mas homens que entendem que o sentido da vida não é a construção de uma sociedade perfeita, plena de homens virtuosos, mas uma que garanta a sobrevivência e seja capaz de organizar as complexas relações sociais de uma coletividade multifacetada em inspirações e anseios.

$\mathrm{Na}$ era da fundação, o Deuteronômio era o livro mais lido entre os colonos, talvez, porque o cultivo da fé era imperativo para garantir a sobrevivência na terra prometida que ainda era muito rústica; porém, no decurso do tempo, a necessidade de organizar a vida cívica relegou o cultivo das virtudes para o fórum pessoal do indivíduo, preocupado em justificar um governo eficiente administrativamente e forte para lidar com os temores externos, como a guerra com outros Estados, e com os internos, a exemplo das lutas intestinas e facções. E ainda que as citações a Maquiavel sejam poucas, e importantes para mensurar a presença de um autor, decerto que a identificação de traços de aceitação e recusa de teses é mais significativa para saber se ocorreu a influência entre autor e leitor e, assim, averiguar a interlocução entre si. Afinal, homens instruídos (HAMILTON; MADISON; JAY, 2003) não deixariam de se imiscuir com as obras maquiavelianas por conta do aspecto religioso. Entretanto, obviamente, tais personagens não estariam dispostos a sofrer sanções pela controversa aproximação, motivo que levou Adams, segundo Thompson (2010), a criticar Maquiavel, e a Jefferson a dizer claramente que todos liam o florentino; neste sentido, mesmo que os homens instruídos não ousassem 
confessar que liam Maquiavel, era imprescindível que o colocassem "ao lado da Declaração de Direitos".

\section{REFERÊNCIAS BIBLIOGRÁFICAS}

BAILYN, Bernard. As origens ideológicas da Revolução Americana. Bauru: EDUSC, 2003.

BALZAC, Honoré de. Ilusões perdidas. São Paulo: Penguin Classics Companhia das Letras, 2011.

BARTUREN, María Begoña Arbulu. Le traduzioni del Principe in Spagna In: Il Principe di Niccolò Machiavelli e il suo tempo: 1513 - 2013. Roma: Treccani, 2013.

BARZUN, Jacques. Da alvorada à decadência: a história da cultura ocidental de 1500 aos nossos dias. Rio de Janeiro: Campus, 2002.

BASSANI, Luigi Marco. Machiavelli and revolutionary America: Beyond the Republican paradigm. In: Anglo american faces: Machiavelli e machiavellismi nella cultura angloamericana (secoli XVI-XX). Milano: Polimetrica, 2009.

BONGI, Salvatore. Un aneddoto di bibliografia Machiavellesca: Lédizione della Storie Fiorentine colla falsa data di Piacenza. In: Archivio Storico Italiano, tomo XIX. G. P. Vieusseux: Firenze, 1897.

COLI, Daniela. Hobbes, Roma e Machiavelli nell'Inghilterra degli Stuarts. Firenze: Casa Editrice le Lettere, 2009.

DANFORD, John W. Getting our bearing: Machiavelli and Hume In: Machiavelli's liberal republican legacy. Cambridge: Cambridge University, 2010.

HAMILTON, Alexander; MADISON, James; JAY, John. O federalista. Belo Horizonte: Líder, 2003.

HARRINGTON, James. The Commonwealth of Oceana. In: The political works of James Harrington, 2 parts. Cambridge: Cambridge University Press, 2010.

HILL, Christopher. A Bíblia inglesa e as raízes e as revoluções do século XVII. Rio de Janeiro: Civilização Brasileira, 2003.

ISAACSON, Walter. Benjamin Franklin: uma vida americana. São Paulo: Companhia das Letras, 2015.

LEFORT, Claude. Maquiavelo: lecturas de lo político. Madrid: Editorial Trotta, 2010.

LUTZ, Donald S. The relative influence of european writers on late Eighteenth-Century american political thought. In: American political Science review. Vol. 78, nº 1 (Mar., 1984), pp. 189-197.

MAQUIAVEL, Nicolau. O Príncipe. São Paulo: 34, 2017.

MAQUIAVEL, Nicolau. Discursos sobre a primeira década de Tito Lívio. São Paulo: Martins Fontes, 2007. 
McCULLOUGH, David G. 1776: a história dos homens que lutaram pela independência dos Estados Unidos. Rio de Janeiro: Jorge Zahar Ed., 2006.

MONTEIRO, João Paulo. O filósofo e a Censura In: Hume e a epistemologia. Vila da Maia: Imprensa Nacional/Casa da Moeda, 1984.

ORSINI, Napoleoe. Studii sul rinascimneto Italiano in Inghilterra: com alcuni testi inglesi inediti. Firenze: G.C. Sansoni, 1937.

PETRINA, Alessandra. Machiavelli in the British Isles: two early modern translation of The Prince. Farnham: Ashgate, 2009.

PETRINA, Alessandra. Machiavelli in Inghilterra e Scozia: il primo secolo del Principe in língua inglese. In: Il Principe di Niccolò Machiavelli e il suo tempo: 1513 - 2013. Roma: Treccani, 2013.

POCOCK, John Greville Agard. The Machiavellian Moment. Florentine political thought and the Atlantic Republican tradition. New Jersey: Princeton, 2003.

POLE, Reginald. Apología ad Carolum Quintum Caesarem In: El Cardenal Pole, de la política como virtud en tempos de El príncipe, Unión Editorial, 2013.

PUIGDOMÈNECH, Helena. Maquiavelo en España. Madrid: Fundación Universitaria Española, 1988.

RAAB, Felix. The English Face of Machiavelli: A changing interpretation 1500 - 1700 (London: Routledge, 2013).

RAHE, Paul A. Machiavelli's liberal republican legacy. Cambridge: Cambridge University, 2010.

RAHE, Paul A. Thomas Jefferson's Machiavellian politicam Science. In: Machiavelli's liberal republican legacy. Cambridge: Cambridge University, 2010.

ROUSSEAU, Jean-Jacques. Do contrato social. Rio de Janeiro: Abril Cultural, 1978.

SPAZZARINI, Alessandra. Le Traduzioni del Principe in Germania In: Il Principe di Niccolò Machiavelli e il suo tempo: 1513 - 2013. Roma: Treccani, 2013.

SPENCER, Mark G. David Hume and Eighteenth-Century America. Rochester: University of Rochester Press, 2005.

TERRENATO, Francesca. Le traduzioni Olandesi del Principe In: Il Principe di Niccolò Machiavelli e il suo tempo: 1513 - 2013. Roma: Treccani, 2013.

THOMPSON, C. Bradley. John Adam's Machiavellian moment. In: Machiavelli's liberal republican legacy. Cambridge: Cambridge University, 2010.

WALLING, Karl-Friedrich. Was Alexander Hamilton a Machiavellian Statesman? In: Machiavelli's liberal republican legacy. Cambridge: Cambridge University, 2010.

WHITFIELD, John Humphreys. The Charlecote Manuscript of Machaiavelli's "Prince'. (Reprinted from Italian Studies, Vol. XXII, 1967).

WOOD, Gordon S. A revolução americana. Rio de Janeiro: Objetiva, 2013. 